\title{
Blackberry cultivars, nitrogen and potassium fertilization under drastic summer pruning in a subtropical area
}

\author{
Luiz Antonio Junqueira Teixeira ${ }^{1, \star}$ (D), José Emílio Bettiol Neto² (D), Juliana Sanches ${ }^{3}$ (D), Rafael Pio ${ }^{4}$ (i) \\ 1. Instituto Agronômico - Centro de Solos e Recursos Ambientais - Campinas (SP), Brazil. \\ 2. Instituto Agronômico - Centro de Frutas - Jundiaí (SP), Brazil. \\ 3. Instituto Agronômico - Centro de Ecofisiologia e Biofísica - Campinas (SP), Brazil. \\ 4. Universidade Federal de Lavras - Departamento de Agricultura - Lavras (MG), Brazil. \\ Received: Dec. 30, 2020 | Accepted: Jul. 1, 2021 \\ Section Editor: Cláudia Sales Marinho \\ *Corresponding author: luiz.teixeira@sp.gov.br \\ How to cite: Teixeira, L. A. J., Bettiol Neto, J. E., Sanches, J. and Pio, R. (2021) Blackberry cultivars, nitrogen and potassium fertilization under \\ drastic summer pruning in a subtropical area. Bragantia, 80, e4921. https://doi.org/10.1590/1678-4499.20200527
}

\begin{abstract}
The expansion of blackberry cropping in subtropical regions is recent, requiring adaptability studies and the development of new cultivars, as well as suitable plant management. Aiming to study adaptability and agronomic performance of blackberry (Rubus spp.) under drastic summer pruning in a subtropical region, the response of four blackberry cultivars ('BRS Tupy', 'Guarani', 'Brazos' and 'Choctaw') to $\mathrm{N}$ and $\mathrm{K}$ fertilization was evaluated during two growing seasons in Jundiaí (Brazil). The experiment used split-plots in a randomized complete block design with four replicates. The plots consisted of combinations of three $\mathrm{N}$ rates $\left(75,150\right.$ and $\left.300 \mathrm{~kg} \cdot \mathrm{ha}^{-1} \cdot \mathrm{year}{ }^{-1}\right)$ and three $\mathrm{K}$ rates $\left(50,100\right.$ and $200 \mathrm{~kg} \cdot \mathrm{ha}^{-1}$.year ${ }^{-1}$ of $\left.\mathrm{K}_{2} \mathrm{O}\right)$ in factorial arrangement and an additional control treatment without fertilizer application. In the subplots, four cultivars of blackberry were studied. Considering fruit yield, accumulation of phytomass and mineral elements, as well as the nutrient efficiency use, the cultivars that showed greater adaptation to cultivation in a subtropical area under drastic summer pruning management are 'Brazos', 'Guarani', 'BRS Tupy' and 'Choctaw', in that order. An annual application of 120 and $67 \mathrm{~kg} \cdot \mathrm{ha}{ }^{-1}$ of N and $\mathrm{K}_{2} \mathrm{O}$, respectively, is expected to be sufficient to achieve maximum economic yield.
\end{abstract}

Key words: Rubus spp., fertilizer recommendation, mineral nutrition, nutritional status, nutrient accumulation.

\section{INTRODUCTION}

Blackberry production has great potential as a viable alternative for fruit growers in subtropical areas, such as southeastern Brazil, as highlighted by Campagnolo and Pio (2012), Moura et al. (2012), Curi et al. (2015) and Croge et al. (2016), among others, and validated by field observations. However, the expansion of blackberry cultivation in subtropical regions is recent and requires adaptability studies for existing cultivars and the development of new ones, as well as pruning and plant management systems (Antunes et al. 2014; Tadeu et al. 2015). Due to the intense plant growth observed in subtropical regions that are warmer than traditional producing regions, it can be assumed that the management of fertilization should also be adjusted, as it likely differs from that in temperate climates.

Currently, the technical recommendations for culture in subtropical areas, as the presented by Martins (1998), need to be updated, especially in relation to plant nutritional management and the productive potential of some cultivars. One of the changes in blackberry production, in order to facilitate management of the orchard, is a drastic annual pruning. This minimizes the infestation of diseases, allowing the plants to produce annually in subtropical regions. In this management, a drastic pruning is performed in the summer, usually in mid-January, after the end of the harvest. Due to the intense growth of blackberries in these regions, all canes are renewed, allowing differentiation of buds before the winter pruning (Campagnolo and Pio 2012; Curi et al. 2015; Tadeu et al. 2015). According to Grandall (1995), dead stems can harbor 
diseases and pests. Thus, removing the entire aboveground part of the plants in a summer pruning could decrease the spread of pests and diseases between crop cycles.

The use of fertilizers in agriculture has an impact on the economic viability of production and on environmental quality, among other aspects; these affect all stakeholders involved, from farmers to society in general (IFA 2016). Singh and Ryan (2015) stated that all crops remove nutrients from the soil. However, when removal exceeds nutrient input, depletion or nutrient "mining" may occur. The excessive use of fertilizer, when greater than the plants demand, implies losses with environmental and economic consequences. The amounts of major nutrients supplied through fertilizers must be based on what is already in the soil and what is removed by the crops. For monitoring purposes, this balance point is calculated as the output/input ratio. Low output/input ratios (e.g., below 50\%) often reflect risks of nutrient losses in the environment, while high ratios (e.g., above 90\%) may reflect soil nutrient mining practices that reduce soil fertility and, if practiced over several years, would not be sustainable (IFA 2016).

One of the major factors guiding fertilization is the replacement of elements exported at harvest and the provision of what is needed to accumulate in plant biomass. Strik and Bryla (2015) stated that blackberry plants have a relatively low nutrient requirement compared with many other perennial fruit crops, but even so, knowing the accumulation of nutrients and the periods of greatest demand is important for the design of fertilization programs. This is especially relevant when setting fertilization programs for regions or managements in which plants have a faster development than in traditional producing areas. As stated by Hart et al. (2006), a fertilization program for blackberries has to be in line with the whole crop management package.

The positive impacts of nitrogen $(\mathrm{N})$ or potassium $(\mathrm{K})$ fertilization on vegetative development and fruit yield of blackberry are described for several growing conditions, as reported by Hart et al. (2006), Strik (2008; 2017), Fernandez-Salvador et al. (2015), Pereira et al. (2015), and Pereira et al. (2020) among others. However, the lack of information relating fertilization to the agronomic performance is total when orchards area managed under drastic summer pruning, in which plants have canes with fruits and primocanes, emitted simultaneously in the same year.

It is observed that the recommendations of $\mathrm{N}$ and $\mathrm{K}$ fertilization for blackberry plants vary significantly according to the source consulted, including Antunes and Raseira (2004) and CQFS (2016) for southern Brazil and Martins (1998) for the southeast region, among others. Even if the criteria for establishing these recommendations vary widely, these differences suggest that such recommendations have been established based on local experimentation, which is subject to variations in edaphoclimatic conditions and productivity potential of different genotypes.

Strik (2017) stated that the peculiar growth habit of blackberry plants, with the accumulation of nutrients in the primocanes and roots, that will strongly remobilize in the period between bud break and fruit production, increases the complexity nutritional management. Perhaps it is even more complex with alternative management with drastic summer pruning in which the plants are forced to emit laterals, differentiate buds, flower and produce in less than a year. Thus, this work aimed to study the response to $\mathrm{N}$ and $\mathrm{K}$ fertilization of four blackberry cultivars ('BRS Tupy', 'Guarani', 'Brazos' and 'Choctaw'), considering soil chemical attributes, nutritional status, nutrient accumulation and plant production, under drastic summer pruning management in a subtropical area.

\section{MATERIAL AND METHODS}

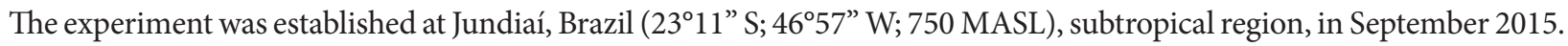

The climate, according to the Köppen climate classification, is Cfa (humid subtropical climate) characterized by hot and humid summers and cold to mild winters. The average temperature is $18.5^{\circ} \mathrm{C}$ and average annual rainfall is about $1,330 \mathrm{~mm}$ (Climate-Data.org 2019). As stated by Pedro Junior et al. (1979), Jundiaí region presents, on average, 60 to $80 \mathrm{~h}$ of cold below $7^{\circ} \mathrm{C}$.

Meteorological data obtained at the station of the Integrated Center for Agrometeorological Information/IAC near the experimental area are summarized in Fig. 1. The soil was classified as ultisol, presenting in 0 to $20 \mathrm{~cm}$ layer before the application of fertilization treatments, organic matter $=19 \mathrm{~g} \cdot \mathrm{kg}^{-1} ; \mathrm{P}_{\text {(resin) }}=9 \mathrm{mg} \cdot \mathrm{dm}^{-3} ; \mathrm{K}=1.8, \mathrm{Ca}=16$ and $\mathrm{Mg}=5 \mathrm{mmol} \cdot \mathrm{dm}^{-3}$ and base saturation $=44 \%$. 

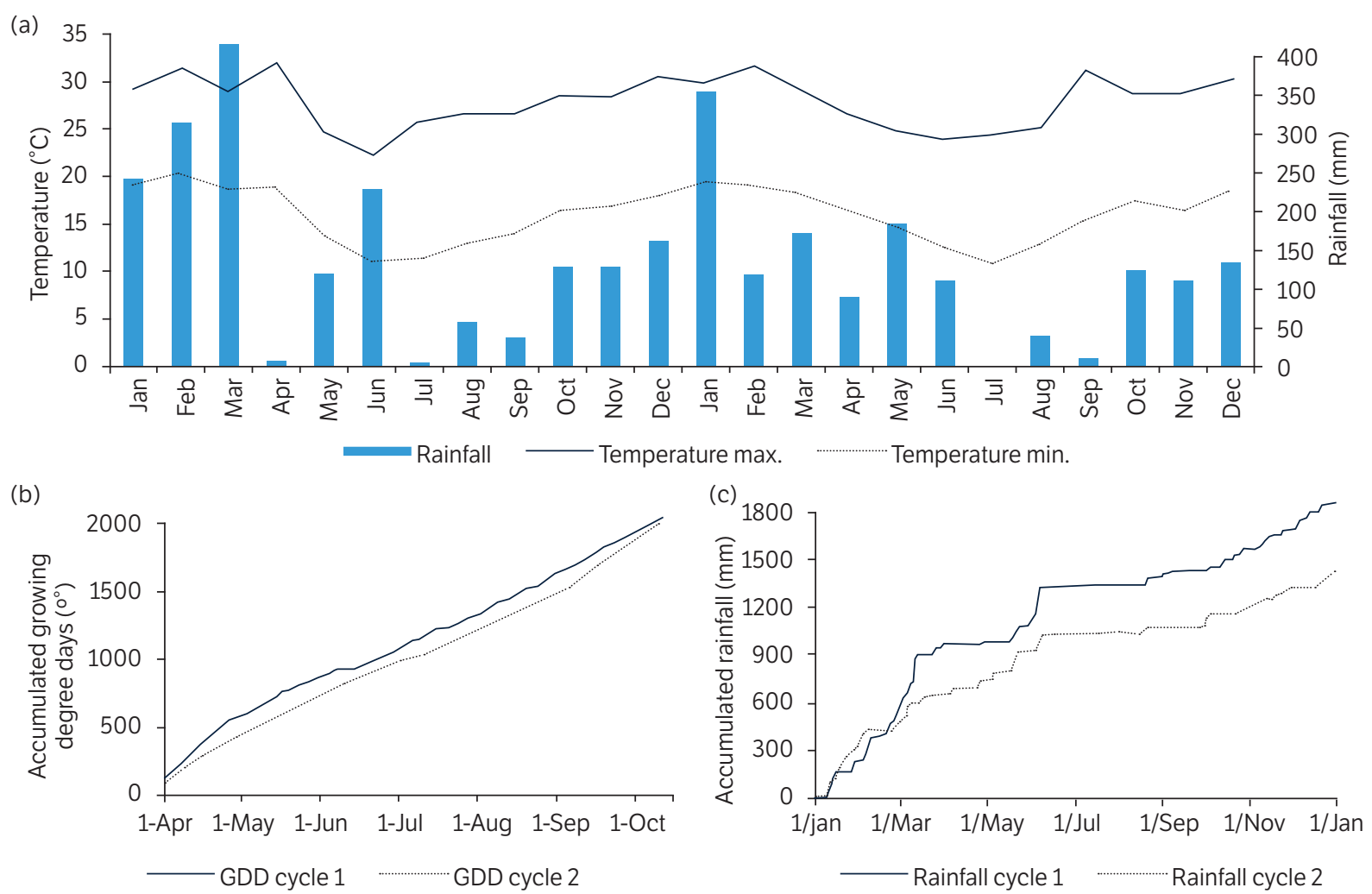

Figure 1. Average rainfall, maximum, minimum temperatures (a) and accumulated rainfall (b) observed during the experimental period (January 2017 to December 2018), and accumulated growing degree days (GDD, Tbase $=10^{\circ} \mathrm{C}$ ) (c) between the selection of the five canes (early April) and the beginning of the harvest (mid-October) of the two cropping cycles, Jundiaí, Brazil.

The field experiment was set up using split-plots in a randomized complete block design with four replicates. Treatments in the main plots consisted of combinations of three doses of $\mathrm{N}\left(75,150\right.$ and $\left.300 \mathrm{~kg} \cdot \mathrm{ha}^{-1} \cdot \mathrm{year}^{-1}\right)$ and three doses of $\mathrm{K}(50$, 100 and $200 \mathrm{~kg} \cdot \mathrm{ha}^{-1} \cdot \mathrm{year}^{-1}$ of $\mathrm{K}_{2} \mathrm{O}$ ) in a factorial arrangement plus an additional control treatment without application of fertilizers. In the subplots, four blackberry cultivars ('BRS Tupy', 'Guarani,', Brazos' and 'Choctaw') were studied. The main plots comprised 28 plants with cultivars distributed in four subplots composed of seven plants each, two plants as guard rows and five for data collection. The whole experiment consisted of 160 experimental units ( 10 plots with the combinations of $\mathrm{N}$ and $\mathrm{K} \times 4$ cultivars $\times 4$ blocks).

The annual doses of fertilizers were applied in two crop cycles. Both $\mathrm{N}$ and $\mathrm{K}$ doses were fractionated in two applications per year. In January, one week after a drastic pruning, 50\% of the annual dose was applied, and the rest of the dose was applied in August. The August application aims to meet the plants needs for the intense growth and the beginning of fruiting that occurs in the spring. Urea $(45 \% \mathrm{~N})$ and potassium chloride $\left(60 \% \mathrm{~K}_{2} \mathrm{O}\right)$ were used as $\mathrm{N}$ and $\mathrm{K}$ sources, respectively. Fertilizers were applied to the soil surface, close to the plant base, on an area of maximum root activity.

Rows were spaced $3 \mathrm{~m}$ apart, and plants were established $0.5 \mathrm{~m}$ apart in each row. To adjust the soil acidity and supply $\mathrm{Ca}$ and $\mathrm{Mg}, 1.1 \mathrm{t} \cdot \mathrm{ha}^{-1}$ of lime (83\% effective neutralizing value) was applied in March 2015. At the bottom of the planting furrow, $1.5 \mathrm{~kg}$.plant ${ }^{-1}$ of organic compost $\left(0.25 \% \mathrm{~N} ; 11.8 \%\right.$ total organic carbon; $245 \mathrm{mmol} \cdot \mathrm{kg}^{-1}$ cation exchange capacity (CEC) was applied. In planting, $150.0 \mathrm{~kg} \cdot \mathrm{ha}^{-1}$ of $\mathrm{P}_{2} \mathrm{O}_{5}, 1.0 \mathrm{~kg} \cdot \mathrm{ha} \mathrm{H}^{-1}$ of $\mathrm{B}$ and $5.5 \mathrm{~kg} \cdot \mathrm{ha}^{-1}$ of $\mathrm{Zn}$ were also applied. A threewire trellis was used to support plants. The top wire was placed at $0.9 \mathrm{~m}$, the middle wire at approximately $0.6 \mathrm{~m}$, and the bottom wire at approximately $0.3 \mathrm{~m}$ from the ground. The orchard was irrigated by drip tubing with $2.5 \mathrm{~L} \cdot \mathrm{h}^{-1} \mathrm{emitters} \mathrm{spaced}$ $0.30 \mathrm{~m}$ apart, located on the soil surface near the base of the plants. Irrigation was applied every two days, as needed, to reach approximately $0.5 \mathrm{~cm} \cdot$ day $^{-1}$ in addition to rainfall. 
The plants were pruned according to the alternative management for subtropical regions proposed by Campagnolo and Pio (2012), Curi et al. (2015) and Tadeu et al. (2015) in which the drastic summer pruning is described. In mid-January, just after the end of the harvest, all canes were cut $0.1 \mathrm{~m}$ from the soil surface and removed from the area. Around the end of March, only the five sturdiest canes per plant were maintained. They were then attached to the wires, and, in mid-June, the tips of the branches were pruned $0.1 \mathrm{~m}$ above the top wire. The winter treatment, aimed at preventive disease control and defoliation, involved the application of lime sulfur mix (12.5\%), urea (10\%) and copper sulphate (2\%). A summary of the main management practices performed in the two cropping cycles is shown in Table 1. The other management practices followed the recommendations of Martins (1998) and Antunes and Raseira (2004).

Table 1. Timeline of key management practices of blackberry plants in two crop cycles.

\begin{tabular}{lcc}
\hline Practice & Cycle 1 & Cycle 2 \\
\hline All cane pruning & Jan. 19 & Jan. 11 \\
\hline Selection of five sturdiest canes & Apr. 4 & Mar. 15 \\
\hline Lime sulfur mix (12.5\%), twice in one day & May 9 & - \\
\hline Urea (10\%) & May 12 & - \\
\hline Pruning of branches tips & Jun. 6 & Jun. 12 \\
\hline Copper sulfate $(2 \%)$, twice in one day & Jun. 10 & Jun. 20 \\
\hline Harvest & Oct. 6 to Dec. 30 & Oct. 22 to Dec. 30 \\
\hline
\end{tabular}

Soil samples were collected in January 2016 and January 2017. The first soil sampling was performed prior to the application of fertilization treatments, and the second was performed right after the drastic pruning (mid-January) of the first cycle and before the first fraction of the annual fertilization for the second cycle. Composite soil samples were taken at depths of 0 to $20 \mathrm{~cm}$ near the plants in the area where fertilizers were usually applied. At each experimental unit, one composite sample (eight subsamples per plot) was collected. The samples were oven-dried at $50{ }^{\circ} \mathrm{C}$ and prepared for chemical characterization. Soil organic matter; $\mathrm{pH}\left(0.01 \mathrm{~mol} \cdot \mathrm{L}^{-1} \mathrm{CaCl}_{2}\right.$ solution); available $\mathrm{P}$, exchangeable $\mathrm{K}$, Ca, and $\mathrm{Mg}$ (extraction by ion exchange resin and determination with inductively coupled plasma optical emission spectrometry - ICP$\mathrm{OES}$ ); soil base saturation; and micronutrient availability (B, extracted with hot water; $\mathrm{Cu}, \mathrm{Fe}, \mathrm{Mn}$ and $\mathrm{Zn}$ extracted with DTPA) were measured according to the methods proposed by van Raij et al. (2001).

To assess plant nutritional status, nutrient contents were analyzed in leaf samples collected from all plots during two cultivation cycles. The $6^{\text {th }}$ fully expanded leaf was selected, counting from the apex. Leaves (leaf blade + pedicel) were collected from canes of the year without flowers (primocanes), in the second half of November, following the recommendations for blackberries in southern Brazil (Antunes and Raseira 2004; CQFS 2016). In November, the plants show canes that have blossomed and are producing fruit (floricane) and branches issued in the year but not yet blossomed (primocanes), on which leaves were collected for nutritional diagnosis. The P, K, Ca, Mg and S leaf contents were determined by ICP-OES after digestion with a mixture of nitric and perchloric acids, and $\mathrm{N}$ leaf content was determined by micro-Kjeldahl (Jones Junior and Case 1990).

In order to estimate blackberry yield, fruits were harvested once a week from mid-October to the end of December, based on their color (shiny black) and ease of separation from the pedicel. All fruits harvested were weighed and counted. Weekly production and cumulative yield in each production cycle were estimated.

After the harvest end of each production cycle (mid-January), all canes were subjected to drastic pruning. This material, as well as the harvested fruits, was weighed and sampled to determine the moisture and $\mathrm{N}, \mathrm{P}, \mathrm{K}, \mathrm{Ca}, \mathrm{Mg}$ and S contents. The accumulated phytomass in each cycle was the sum of fruit mass, branches and leaves removed with drastic pruning; the root mass was not considered. The accumulation of nutrients was estimated by multiplying their contents by the mass of dry matter accumulated in fruits, canes and leaves. These evaluations were carried out in two production cycles. 
Nutrient use efficiency (NUE) was estimated by calculating the agronomic efficiency (AE) and the internal utilization efficiency of a nutrient (IUE) of the applied $\mathrm{N}$ or K. Agronomic efficiency was calculated in units of yield increase per unit of nutrient ( $\mathrm{N}$ or $\mathrm{K}$ ) applied (Eq. 1).

$$
\mathrm{AE}=\frac{(\mathrm{Y}-\mathrm{Yo})}{\mathrm{F}}
$$

where $\mathrm{Y}=$ cumulative fruit yield with $\mathrm{N}$ or $\mathrm{K}$ applied $\left(\mathrm{kg} \cdot \mathrm{ha}{ }^{-1}\right), \mathrm{Yo}=$ cumulative fruit yield obtained in the control treatment without application of $\mathrm{N}$ or $\mathrm{K}$ and $\mathrm{F}=\mathrm{N}$ or $\mathrm{K}$ applied $\left(\mathrm{kg} \cdot \mathrm{ha}^{-1}\right.$ of $\mathrm{N}$ or of $\left.\mathrm{K}_{2} \mathrm{O}\right)$ during two cycles. The IUE was assessed by calculating the fruit yield in relation to the nutrient uptake (IUE = kg yield/kg nutrient uptake), as proposed by Fixen et al. (2015).

The treatment effects were evaluated using analysis of variance (ANOVA). All data were analyzed as a split plot in time with crop cycle as the time factor. As the fertilizer treatments were designed in a factorial scheme (doses of $\mathrm{N}$ and $\mathrm{K}$ ) plus an additional treatment (control, no fertilizer application), the effects of the treatments were analyzed according to Marini (2003). For most of the variables analyzed, the average or cumulative results of the two cultivation cycles were presented and discussed. For those variables that showed different behaviors between cycles ( $F$ test; $p<0.05$ ), the results are presented per cycle. When the effects of cultivars were statistically significant ( $F$ test; $\mathrm{p}<0.05$ ), differences among cultivars were assessed with Tukey's honestly significant difference (HSD) test $(\alpha=0.05)$. For the variables significantly affected by fertilizer the application, $\mathrm{N}$ or $\mathrm{K}$, the quantitative effect of the rates was determined by adjusting regression equations. Following the recommendations of Willcutts et al. (1998) and Hochmuth et al. (2011), a logistic model was adjusted relating the doses of $\mathrm{N}$ or $\mathrm{K}$ to the fruit yield (Eq. 2):

$$
Y=\frac{a}{[1+\exp (b-c X)]}
$$

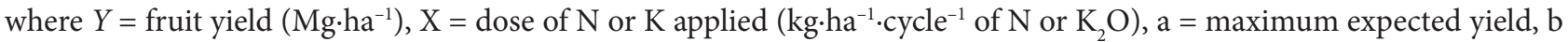
and $\mathrm{c}=$ model parameters. After fitting the model, the appropriate dose would correspond to $95 \%$ of the maximum expected yield. Only statistically significant $(\mathrm{p}<0.05)$ models (equations) are presented. Data were analyzed using SAS statistical package (SAS Institute 2004). The GLM and MIXED procedures were used for ANOVA and regressions, respectively.

\section{RESULTS AND DISCUSSION}

After just one blackberry production cycle, significant effects of $\mathrm{N}$ fertilization on $\mathrm{Ca}$ and $\mathrm{Mg}$ availability were noted, along with attributes related to soil acidity, such as $\mathrm{pH}$ and base saturation. Increasing $\mathrm{N}$ rates significantly decreased soil $\mathrm{pH}$ and base saturation. The application of $100 \mathrm{~kg} \cdot \mathrm{ha}^{-1}$ of $\mathrm{N}$ caused a reduction of $0.4 \mathrm{pH}$ units after one crop cycle. The base saturation was likewise impacted by $\mathrm{N}$ application (Fig. 2). The soil $\mathrm{Ca}$ and $\mathrm{Mg}$ availability were also negatively affected by $\mathrm{N}$ application (Fig. 3). The natural processes of soil acidification in tropical regions, such as the loss of cations by leaching, which are associated with the effects of cultivation resulting from, among other things, the use of urea and ammoniacal sources in N fertilization, can threaten the sustainability of crops. Tian and Niu (2015) presented the general effects of $\mathrm{N}$ application on increasing soil acidity, and Strik (2017) detailed this relationship specifically in the context of blackberry orchards. It was reported that for medium-textured soil in Oregon (temperate region), the application of $112 \mathrm{~kg} \cdot \mathrm{ha}^{-1}$ of urea in a blackberry orchard determines an average reduction of $0.1 \mathrm{pH}$ units per year. This impact on soil acidity due to the use of $\mathrm{N}$ in tropical regions cultivated with fruits may be greater, as observed in this experiment and also reported by Pereira et al. (2020) with blackberries grown in southern Brazil. The increase in cation absorption by plants, together with the acidification resulting from the application of $\mathrm{N}$, determined a significant decrease in soil $\mathrm{Ca}$ and $\mathrm{Mg}$ availability and in base saturation. Strik (2017) expressed a concern about the calcium supply to blackberry fruits. According to her, there is evidence in many fruit crops that the Ca concentration in fruit is related to firmness or storage life. Natale et al. (2012) reported that, in fruit orchards in Brazil, the application of repeated high-dose $\mathrm{N}$ in restricted areas (plant canopy projection) worsens the soil acidity problem, consequently requiring regular monitoring with chemical soil analysis. 

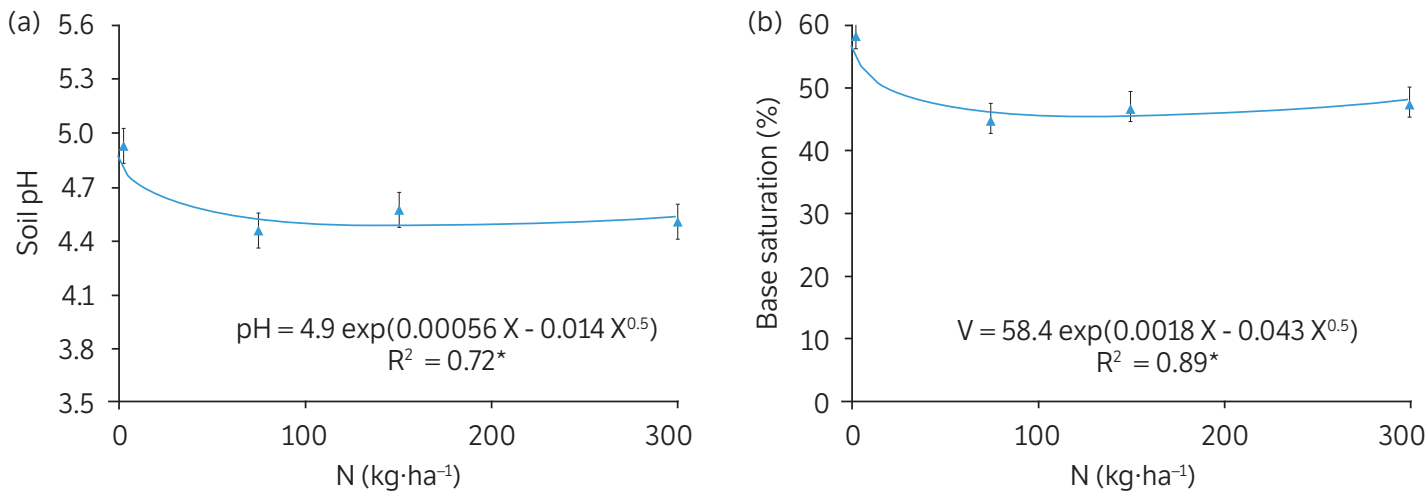

Figure 2. Soil acidity (a) and base saturation (b) in 0 to $20 \mathrm{~cm}$ soil layer as a function of $\mathrm{N}$ fertilization in blackberry plants after one year of cultivation. Note. Whiskers represent $95 \%$ confidence intervals of means. ${ }^{*} 0.01<p<0.05$.
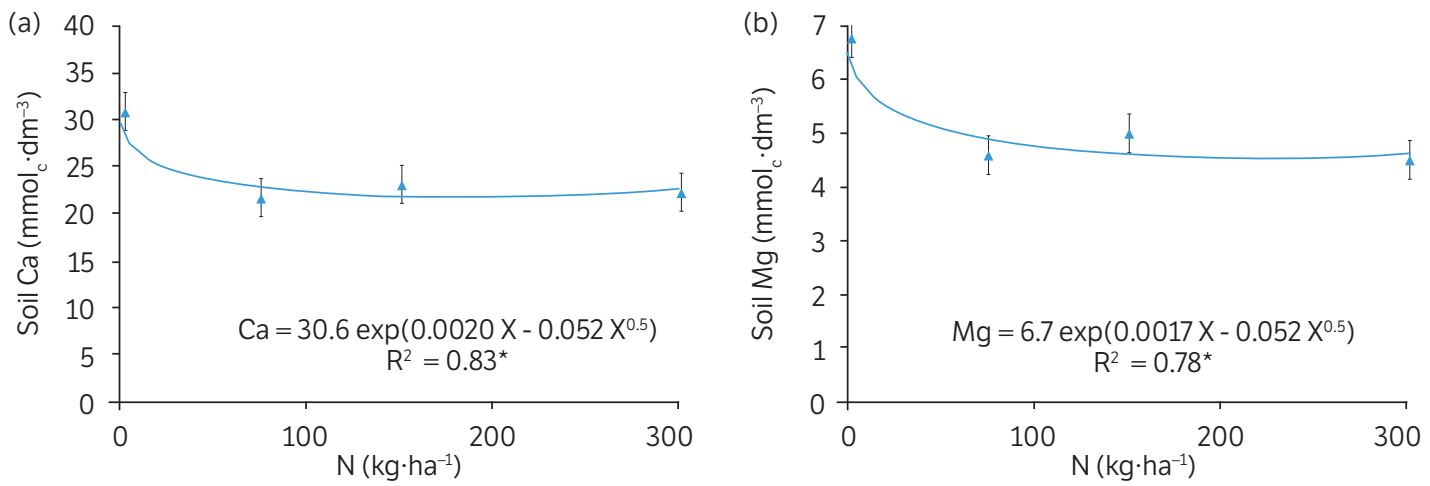

Figure 3. Calcium (a) and $\mathrm{Mg}$ (b) availability in 0 to $20 \mathrm{~cm}$ soil layer as a function of $\mathrm{N}$ fertilization in blackberries after one year of cultivation. Note. Whiskers represent $95 \%$ confidence intervals of means. ${ }^{*} 0.01<p<0.05$.

Potassium fertilization, as expected, increased soil $\mathrm{K}$ availability, which favors the nutrition of orchard plants. However, $\mathrm{K}$ application also had a negative effect, causing a significant decrease in $\mathrm{Mg}$ availability, indicating the need to monitor soil fertility in order to minimize possible nutritional imbalances (Fig. 4). Spiers and Braswell (2002) in nutrient solution and Pereira et al. (2015) in field conditions in southern Brazil reported antagonistic effects between Kapplication and the absorption of Ca and $\mathrm{Mg}$ by blackberry; however, neither study included information about the $\mathrm{Ca}$ or $\mathrm{Mg}$ availability in the soil or in the nutrient solution.
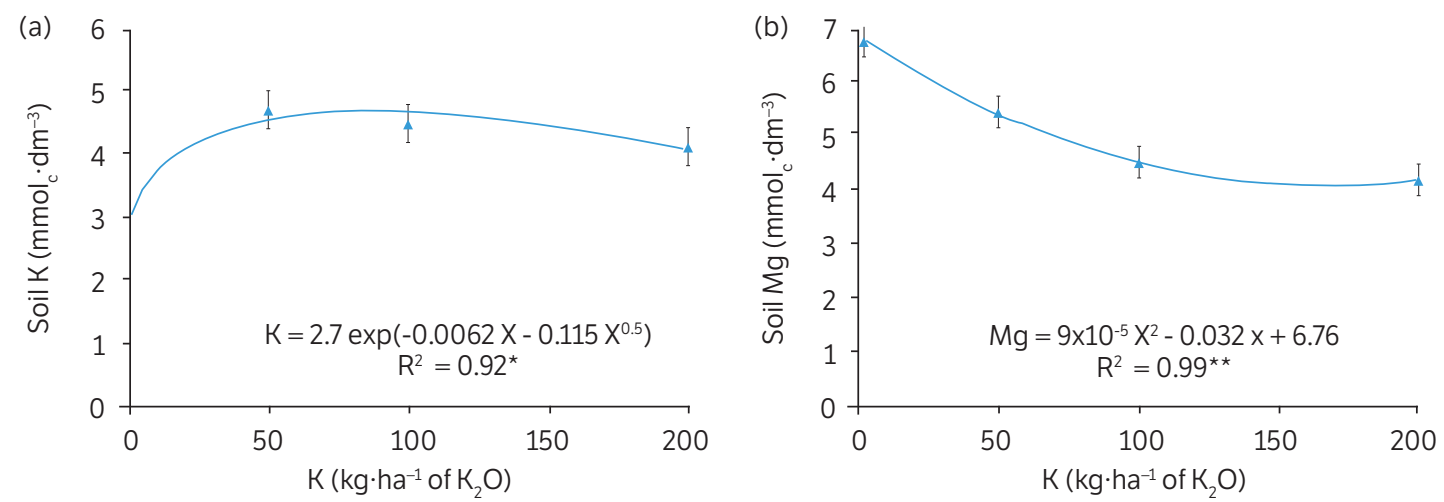

Figure 4. Potassium (a) and $\mathrm{Mg}$ (b) availability in the 0 to $20 \mathrm{~cm}$ soil layer as a function of potassic fertilization in blackberry after one year of cultivation. Note. Whiskers represent $95 \%$ confidence intervals of means. ${ }^{* \star} p<0.01 ;{ }^{*} 0.01<p<0.05$.

Organic matter and $\mathrm{P}$ availability were not affected by either $\mathrm{N}$ or $\mathrm{K}$ applications. Likewise, the interaction between the effects of $\mathrm{N}$ and $\mathrm{K}$ was not statistically significant (F test; $\mathrm{p}>0.05$ ). 
The nutritional status of blackberry plants was assessed by means of tissue analysis. Significant differences (Tukey's HSD test; $\mathrm{p}<0.05$ ) were observed among cultivars regarding the leaf contents of $\mathrm{N}, \mathrm{K}, \mathrm{Ca}, \mathrm{Mg}$ and S (Fig. 5). The leaf P concentration did not show significant variation among cultivars (Tukey's HSD test; $\mathrm{p}>0.05$ ). Although the cultivars showed different patterns of leaf mineral-element contents, the simple observation of these values does not allow direct association of these differences with nutritional requirements. For N, Ca, Mg and S, 'Choctaw' showed the highest leaf content of these elements, but this cultivar presented the least dry-matter accumulation (Fig. 6). These results may be associated with the dilution effect, which occurs when mineral-element concentrations in shoots decrease as shoot-dry-matter accumulation increases (Riedell 2010). Hart et al. (2006) and Strik (2017) highlighted the importance of considering plant growth when interpreting the results of foliar analysis with blackberries.
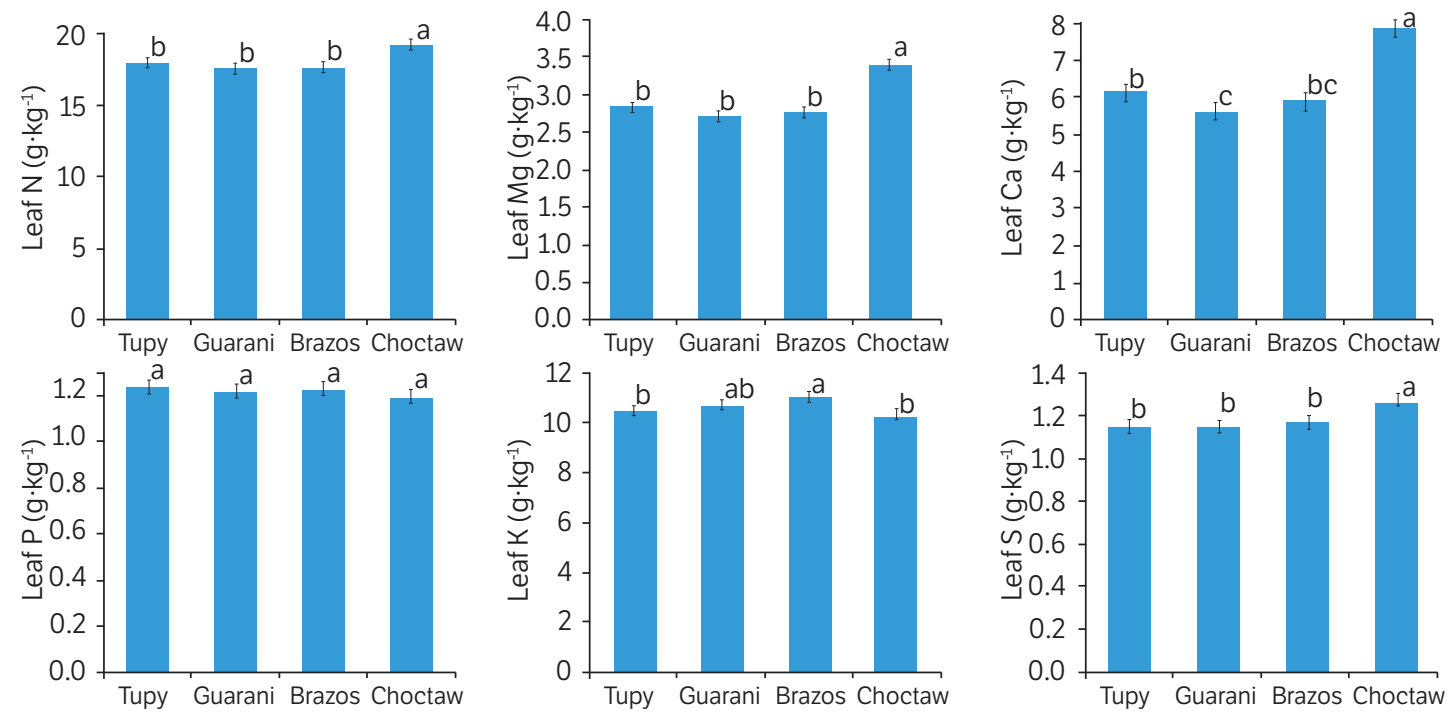

Figure 5. Nitrogen, $\mathrm{P}, \mathrm{K}, \mathrm{Ca}, \mathrm{Mg}$ and $\mathrm{S}$ leaf contents of four blackberry cultivars.

Note. Bars headed by different letters indicate that nutrient leaf contents differ among cultivars (Tukey's HSD test, $p<0.05$ ). Means of the values observed in two cultivation cycles. Whiskers represent $95 \%$ confidence intervals of means.
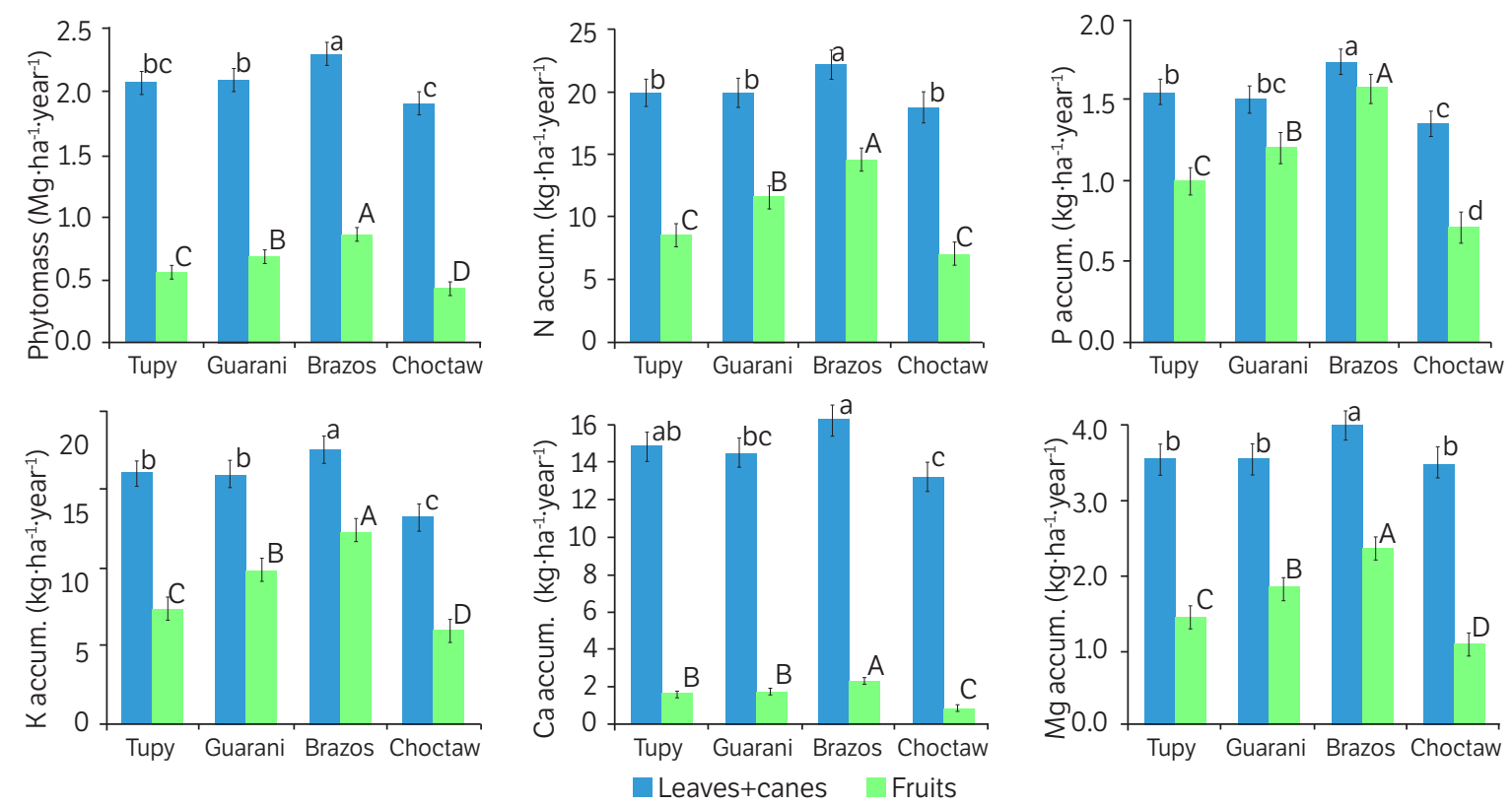

Figure 6. Phytomass (dry mass) and N, P, K, Ca and Mg accumulation in plant shoot dry-matter (canes + leaves) and in fruits of four blackberry cultivars.

Note. Bars headed by different upper-case letters indicate that the amount accumulated in fruits differed among cultivars; lower-case letters indicate that the amount accumulated in leaves + canes differed among cultivars (Tukey's HSD test, $p<0.05$ ). Means of the values observed in two cultivation cycles. Whiskers represent the $95 \%$ confidence intervals of the means. 
Regarding the effects of fertilizer treatments, $\mathrm{N}$ and $\mathrm{K}$ fertilization were found to produce a significant linear increase in $\mathrm{N}$ and $\mathrm{K}$ leaf contents, respectively (Fig. 7). There were no significant effects of $\mathrm{N}$ fertilization or $\mathrm{K}$ on the leaf contents of $\mathrm{P}, \mathrm{Ca}, \mathrm{Mg}$ and $\mathrm{S}$. The interaction effect between cultivars and fertilization on plant nutrition status was also not significant in either cycle ( $F$ test; $p>0.05)$.
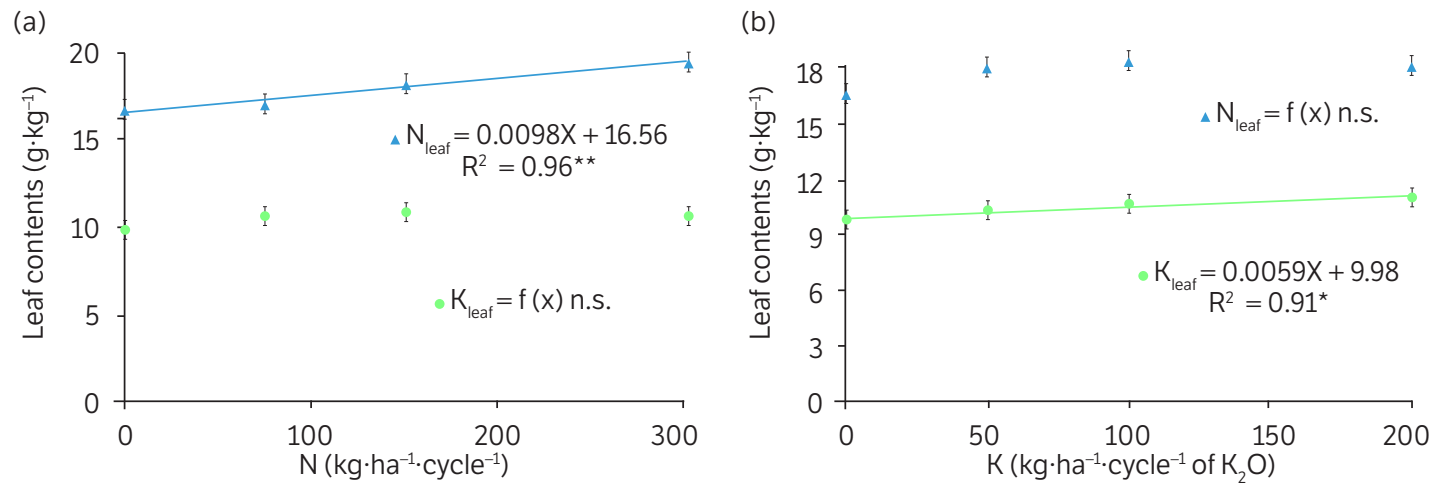

Figure 7. Nitrogen and $\mathrm{K}$ leaf contents of blackberries as a function of $\mathrm{N}(\mathrm{a})$ and $\mathrm{K}(\mathrm{b})$ doses.

Note. Means of the values observed in two cultivation cycles. Whiskers represent $95 \%$ confidence intervals of means. ${ }^{\star \star} p<0.01$; ${ }^{*} 0.01<p<0.05$.

The mineral-element leaf contents observed in this work (Fig. 5), especially $\mathrm{N}$ and $\mathrm{K}$, were consistently below the standard reference values for southern Brazil (CQFS 2016), as well as in comparison with standards for orchards in the USA (Strik 2017). Even with the maximum dose of $\mathrm{N}$ and $\mathrm{K}$, the leaf contents of these elements (Fig. 7) did not reach the recommended minimum values of $22 \mathrm{~g} \cdot \mathrm{kg}^{-1}$ for $\mathrm{N}$ and $12.5 \mathrm{~g} \cdot \mathrm{kg}^{-1}$ for $\mathrm{K}$ (CQFS 2016); however, this does not imply that the blackberry plants of this study were deficient. Due to the pruning management adopted in this experiment (summer drastic pruning), plant nutritional status assessment through comparisons of observed mineral-element contents with reference values may be impaired. In order to achieve meaningful comparisons and interpretations, it is mandatory that the sampling (part of the plant, timing etc.), as well as the analysis, are standardized (Jones Junior and Case 1990). As the plants in this work had canes with fruits and primocanes emitted simultaneously in the same year, comparisons with standard values established for floricane cultivars pruned by conventional methods may not be entirely reliable. Regarding the widely used nutritional standards for blackberries in Brazil, Antunes et al. (2014) reported an even more critical situation, since the optimum levels of leaf nutrients were originally developed for raspberries. These authors highlighted the importance of studies to validate and improve these standards, as they are important for the precise management of nutrition in blackberry orchards.

A significant association was observed between leaf $\mathrm{N}$ and $\mathrm{K}$ levels and fruit yield, indicating that part of the variation in fruit production may be influenced by the nutritional status of the plants (Fig. 8). The relationship between plant nutritional status and fruit yield that was observed in two growth cycles confirms the importance of $\mathrm{N}$ and $\mathrm{K}$ fertilization as a key production feature, as presented in by Hart et al. (2006), Fernandez-Salvador et al. (2015), Strik (2017), Pereira et al. (2015), Pereira et al. (2020) and other authors.

Plant phytomass (canes + leaves and fruits), expressed on a dry basis, as well as the accumulated amounts of N, P, $\mathrm{K}, \mathrm{Ca}$ and $\mathrm{Mg}$ per cycle, are shown in Fig. 6. In general, the cultivar 'Brazos' accumulated larger amounts of phytomass and, therefore, nutrients, than 'Guarani', 'BRS Tupy' and 'Choctaw', in that order. The significant differences in nutrient accumulation observed between cultivars indicate that the fertilizer recommendations must be adjusted according to the potential for biomass accumulation of the plants. An interesting approach for establishing fertilizer doses for some crops is to consider an expected yield, in which plants that accumulate more have higher fertilizer recommendations. In the state of São Paulo, this approach for different crops is described in van Raij et al. (1997). The last update of fertilizer recommendation for blackberry in the South of Brazil also takes into account the productivity in the estimation of N, P and K doses (CQFS 2016). Thus, based on these results, it is reasonable to assume that the recommended fertilizer doses should be higher for 'Brazos' than for 'Choctaw'. 
(a)

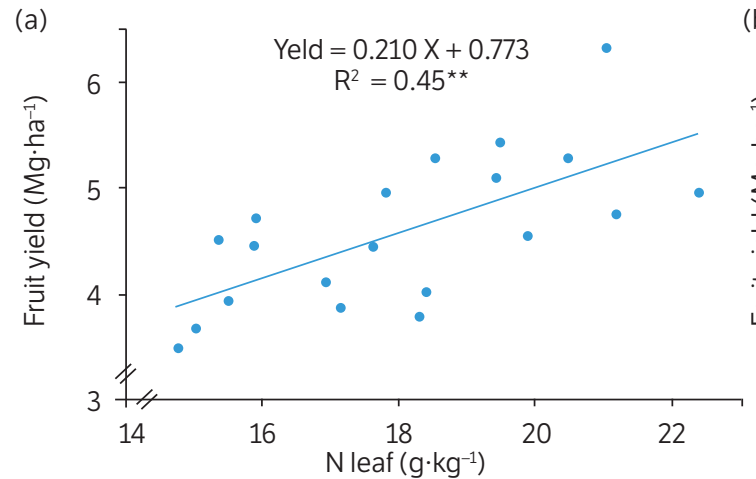

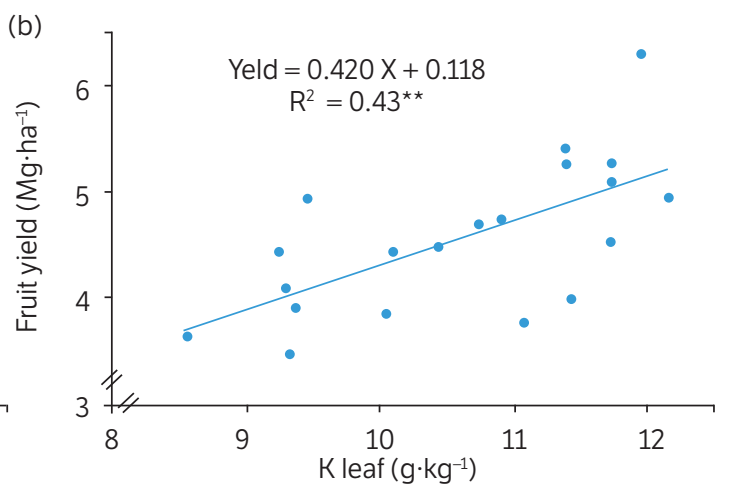

Figure 8. Relationship between leaf $\mathrm{N}(\mathrm{a})$ and $\mathrm{K}(\mathrm{b})$ contents and blackberry fruit yield in two production cycles.

Note. ${ }^{* \star} \mathrm{p}<0.01$.

The interaction effect between cultivars and fertilization on plant phytomass (leaves + canes + fruits) or nutrient accumulation was not significant in either cycle (F test; $\mathrm{p}>0.05$ ). Otherwise, phytomass production by blackberry plants increases significantly with $\mathrm{N}$ fertilization. The application of $200 \mathrm{~kg} \cdot \mathrm{year}^{-1}$ of $\mathrm{N}$ increased the dry matter accumulated by about $30 \%$ in relation to the control treatment (Fig. 9a). In general, plants with a deficient $\mathrm{N}$ supply exhibit a stunted appearance, reduced leaf area and chlorosis. This is due to the function of $\mathrm{N}$ in the constitution of proteins, nucleic acids, chlorophyll, coenzymes, phytohormones and secondary metabolites (Hawkesford et al. 2012). Specifically for blackberry, the importance of adequate supply of $\mathrm{N}$ was discussed by Strik (2008; 2017), in which the main indicator of N sufficiency would be cane growth.
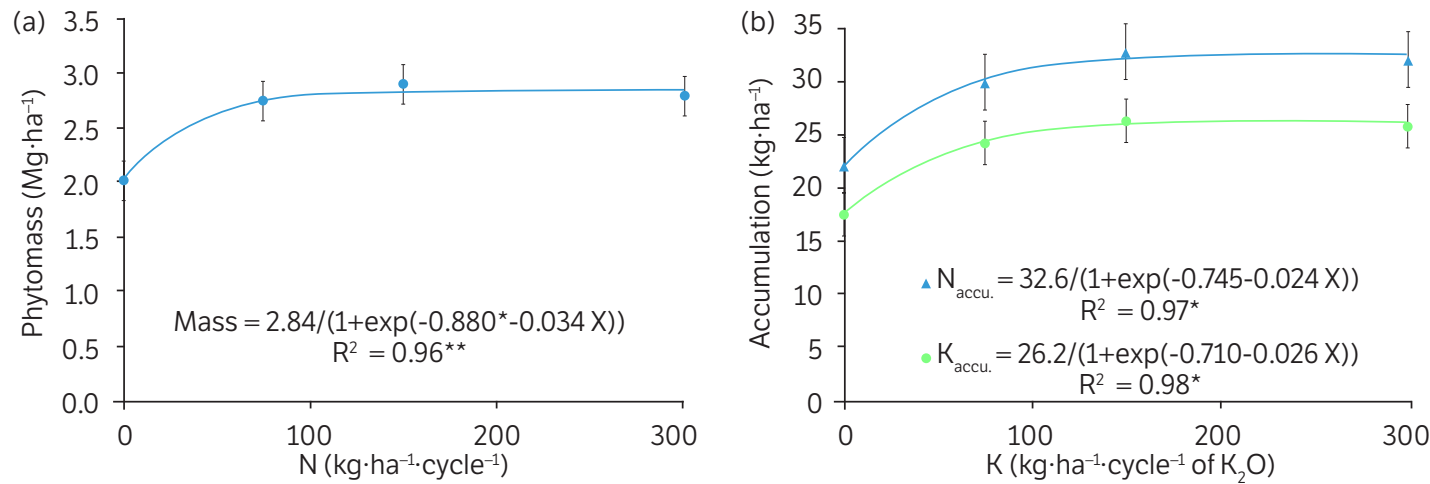

Figure 9. Phytomass (dry mass of canes + leaves + fruits) (a), $\mathrm{N}$ and $\mathrm{K}$ accumulation (b) in blackberry plants as a function of $\mathrm{N}$ doses.

Note. Means of the values observed in two cultivation cycles. Whiskers represent the $95 \%$ confidence intervals of the means. ${ }^{* \star} p<0.01$.

Nitrogen fertilization, while determining a significant increase in plant biomass, also raised $\mathrm{K}$ accumulation by the four blackberry cultivars (Fig. 9b). Without applying $\mathrm{N}$, it was estimated that approximately $18 \mathrm{~kg} \cdot \mathrm{ha}^{-1} \cdot \mathrm{year}^{-1} \mathrm{of} \mathrm{K}_{2} \mathrm{O}$ was exported by the plants; when applying approximately $150 \mathrm{~kg} \cdot \mathrm{ha}^{-1} \cdot \mathrm{year}^{-1}$ of $\mathrm{N}$, K exports rose to $26 \mathrm{~kg} \cdot \mathrm{ha}^{-1} \cdot \mathrm{year}^{-1}$ of $\mathrm{K}_{2} \mathrm{O}$. As the $\mathrm{K}$ content in plant biomass did not vary as a function of $\mathrm{N}$ fertilization ( $\mathrm{F}$ test; $\mathrm{p}>0.05$ ), the increase in $\mathrm{K}$ accumulation was a consequence of the biomass increment caused by $\mathrm{N}$ application. This trend of increasing nutrient accumulation as a result of increasing plant biomass was also observed for all other macronutrients during two crop cycles (data not shown). The accumulation and export increase of other nutrients, such as $\mathrm{K}$, induced by $\mathrm{N}$ fertilization requires care with their replacement.

Disregarding the efficiency of fertilizer use, the ideal proportion among N:P:K application should be approximately 10:02:10, respectively, in order to meet the proportion of these nutrients accumulated in the phytomass of blackberry plants grown in the presence of drastic summer pruning. The common practice of fertilizing based on the appearance of 
the orchard, as vigor or intense green, normally very dependent on $\mathrm{N}$ application, has the potential to induce deficiencies of other nutrients whose exportation increases with the use of $\mathrm{N}$.

Fertilizers must be used to seek the maintenance, or possible improvement, of soil fertility, as well as fruit production sustainability. Considering the annual accumulation of $\mathrm{N}, \mathrm{P}$ and $\mathrm{K}\left(37,8\right.$ and $36 \mathrm{~kg} \cdot \mathrm{ha}^{-1} \cdot \mathrm{year}^{-1}$ of $\mathrm{N}, \mathrm{P}_{2} \mathrm{O}_{5}$ and $\mathrm{K}_{2} \mathrm{O}$, respectively) by the cultivar 'Brazos' (average values for all doses of $\mathrm{N}$ and $\mathrm{K}$ ) under management with drastic summer pruning and an average fertilizer use efficiency (less than $50 \%$ for $\mathrm{N}$, less than $10 \%$ for $\mathrm{P}$, and approximately $40 \%$ for $\mathrm{K}$ as reported by Baligar et al. 2001), it is reasonable to estimate that the minimum annual doses of $\mathrm{N}, \mathrm{P}$ and $\mathrm{K}$ would be approximately 74, 75 and $90 \mathrm{~kg} \cdot \mathrm{ha}^{-1} \cdot \mathrm{year}^{-1}$ of $\mathrm{N}, \mathrm{P}_{2} \mathrm{O}_{5}$, and $\mathrm{K}_{2} \mathrm{O}$, respectively. The doses of $\mathrm{N}_{2} \mathrm{P}_{2} \mathrm{O}_{5}$ and $\mathrm{K}_{2} \mathrm{O}$ most commonly used in orchards in the USA (56-90 kg.ha-1 of N; 67-90 kg.ha-1 of $\mathrm{P}_{2} \mathrm{O}_{5} ; 45-112 \mathrm{~kg} \cdot \mathrm{ha}^{-1}$ of $\mathrm{K}_{2} \mathrm{O}$ ) reported by Strik (2017) are close to the minimum doses estimated from the observed data. Fertilizer annual doses recommended for the southern region of Brazil, considering the characteristics of the orchard, are 180, 82 and $142 \mathrm{~kg} \cdot \mathrm{ha}^{-1} \cdot \mathrm{year}^{-1}$ of N, $\mathrm{P}_{2} \mathrm{O}_{5}$ and $\mathrm{K}_{2} \mathrm{O}$, respectively (CQFS 2016). These doses apparently would supply the demand for $\mathrm{N}$ and $\mathrm{K}$ of the plants. So, probably, all absorption and exportation of $\mathrm{K}$ by plants could be replenished by fertilization. There are no details regarding orchard management with these recommendations, but it is probably for biennial production and not for management with drastic summer pruning and annual production.

In both crop cycles, some variations were observed among the genotypes regarding harvest distribution and fruit yield. In Fig. 10 the cumulative distribution of fruit production over the harvests during two crop cycles is shown. As a whole, in the second cycle there was a delay in the harvest compared to the previous year. In the first cycle, the cultivars 'BRS Tupy', 'Guarani' and 'Brazos' had already produced about $20 \%$ of the total fruit in the first thirty days of harvest, whereas in the second cycle, all cultivars had produced less than $5 \%$ of the total fruit of the harvest in the first month. Interestingly, in both cycles, on average, 50\% of fruit production was achieved around the second month of harvest. Comparing the two cycles, differences common to all cultivars were noticed, as the anticipation of harvest beginning and the higher percentage of fruits picked in a shorter period in the first cycle. This variation in blackberry phenology could be attributed, according to Antunes et al. (2010), to the intrinsic genetic characteristics of each cultivar, as well as climatic factors such as temperature and photoperiod. In this study, differences between cycles may be related to the greater accumulation of cold hours during winter and the higher rainfall in the first in relation to the second cycle (Fig. $1 \mathrm{~b}$ and c). Realizing that genotypes can have significant differences that make it possible to extend the harvest period is relevant for fruit growers, as it indicates the possibility of staggering production. The result can be the supply of fruit for a longer period, positively impacting the cash flow.
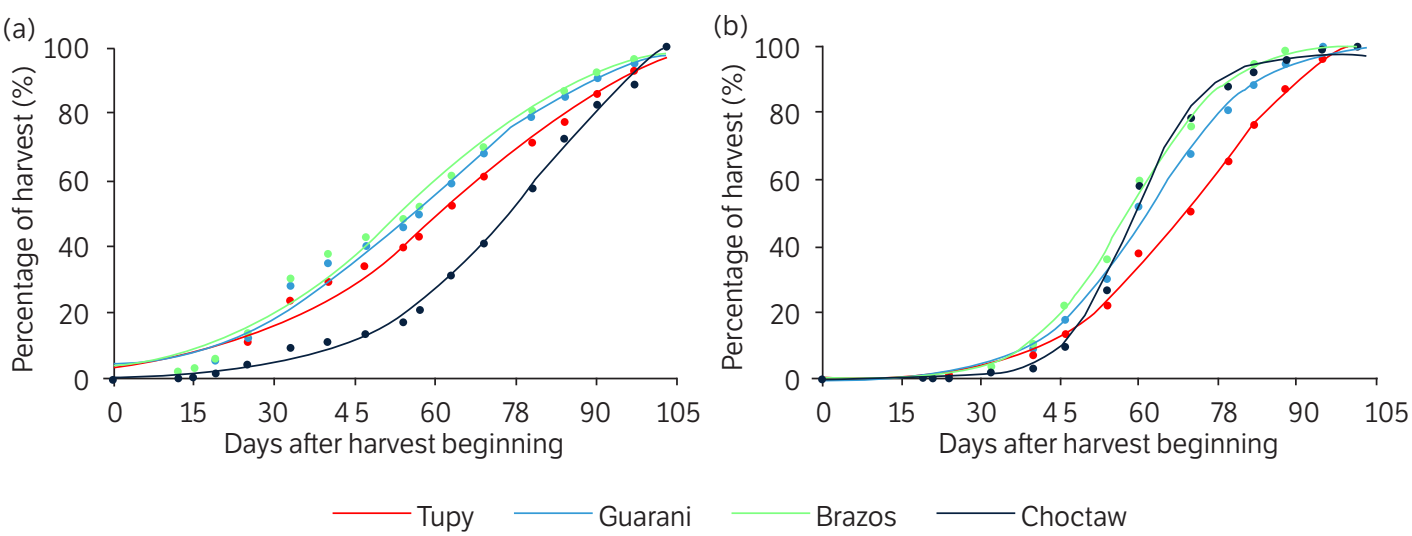

Figure 10. Cumulative harvest percentage as a function of time of four blackberry cultivars during the first (a) and second (b) cycles.

The $\mathrm{N}$ or $\mathrm{K}$ application had no effect on the distribution of the harvest throughout the cycles. There were also no effects of the interaction between cultivars and fertilization ( $F$ test; $\mathrm{p}>0.05$ ). The importance of nutrition for plant vegetative development, especially in relation to N, was highlighted by Pereira et al. (2020) and Strik (2017), among others. However, 
reports of the direct effects of $\mathrm{N}$ or K fertilization on the length of blackberry phenological stages are scarce. Strik (2008) reported that an increase of $\mathrm{N}$ availability shortened the flowering period in some varieties of the genus Rubus, but also stated that this observation did not apply to all varieties.

Regarding fruit production, there was no crop cycle and fertilizer treatments interaction (F test; $\mathrm{p}>0.05$ ), so cumulative yield could be compared statistically. The cumulative fruit yield obtained at the end of two harvests varied significantly among the four cultivars, with the yield ranking among them remaining approximately constant in the two production cycles (Fig. 11). The most productive cultivar, 'Brazos', yielded approximately $100 \%$ more than the least productive, 'Choctaw'.

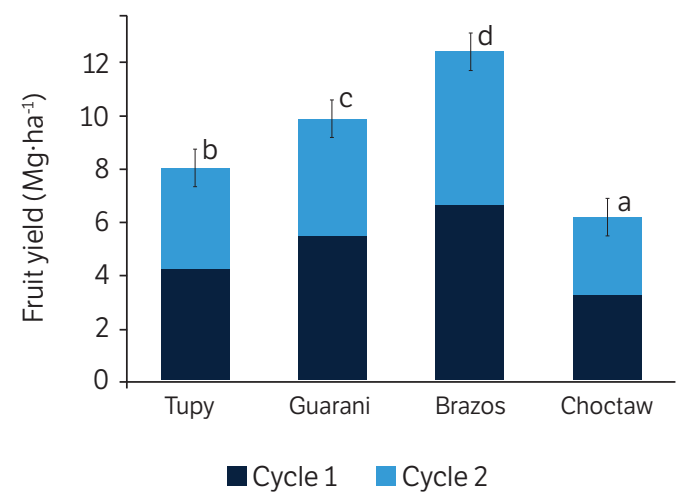

Figure 11. Cumulative fruit yield of four blackberry cultivars.

Note. Bars headed by different letters indicate that the cumulative yields differed among cultivars (Tukey's HSD test, $p<0.05$ ). Whiskers represent the $95 \%$ confidence intervals of the means.

There was a positive effect of both $\mathrm{N}$ and $\mathrm{K}$ fertilization on the cumulative fruit yield (Fig. 12). After fitting the logistic model, the appropriate dose would correspond to 95\% of the maximum expected yield. According Hochmuth et al. (2011), this procedure to estimate the adequate dose would result in profitable returns, saving expenses with fertilizer and reducing the risk of excessive fertilizer applications that might endanger the environment. To obtain $95 \%$ of the maximum cumulative yield as a target to be achieved with the application of $\mathrm{N}, 9.3 \mathrm{Mg} \cdot \mathrm{ha}^{-1} \cdot \mathrm{year}^{-1}$ in two production cycles, it was necessary to apply approximately $120 \mathrm{~kg} \cdot \mathrm{ha}^{-1} \cdot \mathrm{cycle}^{-1}$ of N. For potassium fertilization, $95 \%$ of the maximum yield, $9.2 \mathrm{mg} \cdot \mathrm{ha}^{-1}$, was achieved by applying approximately $67 \mathrm{~kg} \cdot \mathrm{ha}^{-1} \cdot \mathrm{cycle}^{-1}$ of $\mathrm{K}_{2} \mathrm{O}$. Compared to the fertilizer recommendation for blackberries in southern Brazil, 180 and $142 \mathrm{~kg} \cdot \mathrm{ha}^{-1} \cdot \mathrm{year}^{-1}$ of $\mathrm{N}$ and $\mathrm{K}_{2} \mathrm{O}$, respectively (CQFS 2016), the recommended $\mathrm{N}$ dose is $50 \%$ higher than that estimated requirement in this experiment, and the $\mathrm{K}$ dose is more than double that which was sufficient to achieve $95 \%$ of the maximum yield.
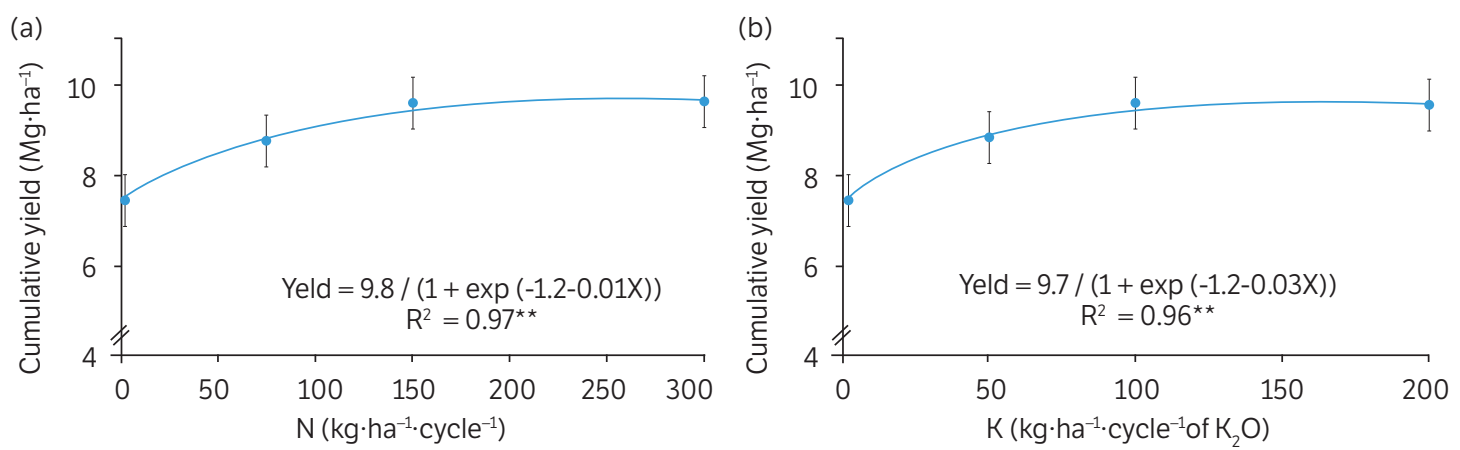

Figure 12. Cumulative fruit yield of blackberry during two crop cycles as a function of $N(a)$ and $K(b)$ doses.

Note. Whiskers represent the $95 \%$ confidence intervals of means; ${ }^{* *} \mathrm{p}<0.01$. 
The NUE of $\mathrm{N}$ and $\mathrm{K}$ fertilizer applied, estimated by the AE, varied significantly depending on blackberry cultivars (Fig. 13). The differences in fruit yield between cultivars (Fig. 11) strongly affected NUE of fertilizers containing $\mathrm{N}$ and $\mathrm{K}$ among them. That is, for each $\mathrm{kg}$ of $\mathrm{N}$ applied to 'Brazos', it was possible to produce $12.4 \mathrm{~kg}$ of fruits, while with 'Choctaw' it was produced around $1 \mathrm{~kg}$ of fruit per $\mathrm{kg}$ of $\mathrm{N}$ applied. For $\mathrm{K}$ fertilization, this difference was even greater, $1 \mathrm{~kg}$ of $\mathrm{K}$ yielded $18 \mathrm{~kg}$ of fruits with 'Brazos', while 'Choctaw' produced only $1 \mathrm{~kg}$ of fruits per $\mathrm{kg}$ of K applied.

(a)

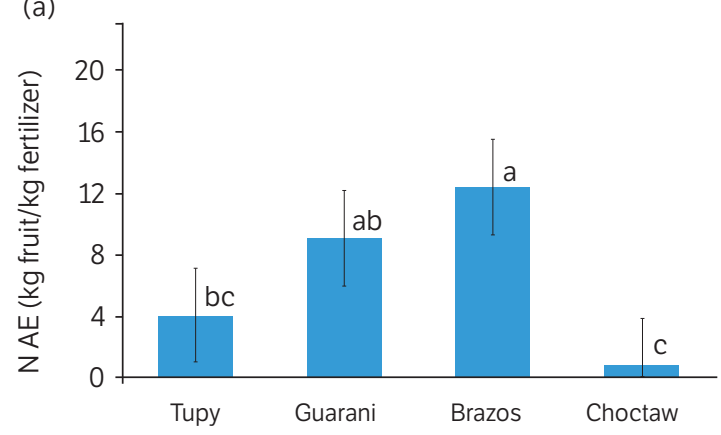

(b)

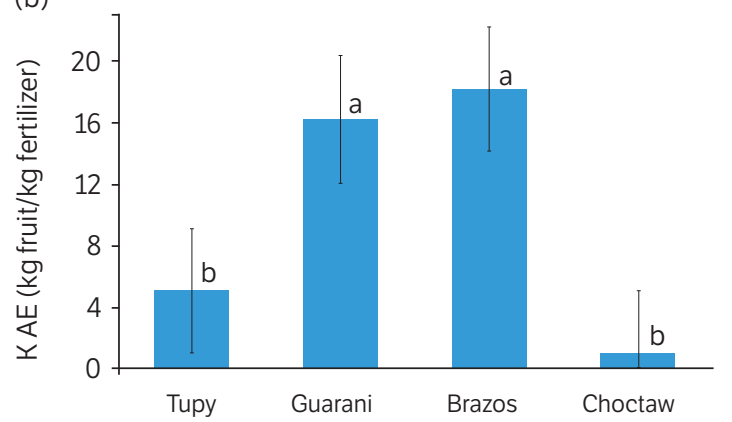

Figure 13. Agronomic efficiency (AE) of $\mathrm{N}(\mathrm{a})$ and of $\mathrm{K}(\mathrm{b})$ applied in four blackberry cultivars.

Note. Bars headed by different letters indicate that AE of $\mathrm{N}$ or K differed among cultivars (Tukey's HSD test, $\mathrm{p}<0.05$ ). Whiskers represent the $95 \%$ confidence intervals of means.

The efficiency of the transformation of absorbed N, P, Ca, Mg, and S into yield (IUE) also showed significant variation among cultivars (Fig. 14). For almost all the nutrients analyzed, 'Guarani' and 'Brazos' were more efficient than 'BRS Tupy' and 'Choctaw' in transforming the nutrients accumulated in the phytomass into fruits (Fig. 9). According to Fixen et al. (2015), variations in the IUE between genotypes indicate their adaptability in a given cultivation condition; so, based on this assumption, 'Brazos' and 'Guarani' are probably more adapted to the local growing conditions, including soil, climate and management practices. Likewise, it is possible that the IUE is even more important under management in which plants have to transform the absorbed nutrients into production in shorter periods, such as annual production with drastic summer pruning, than under conventional management.
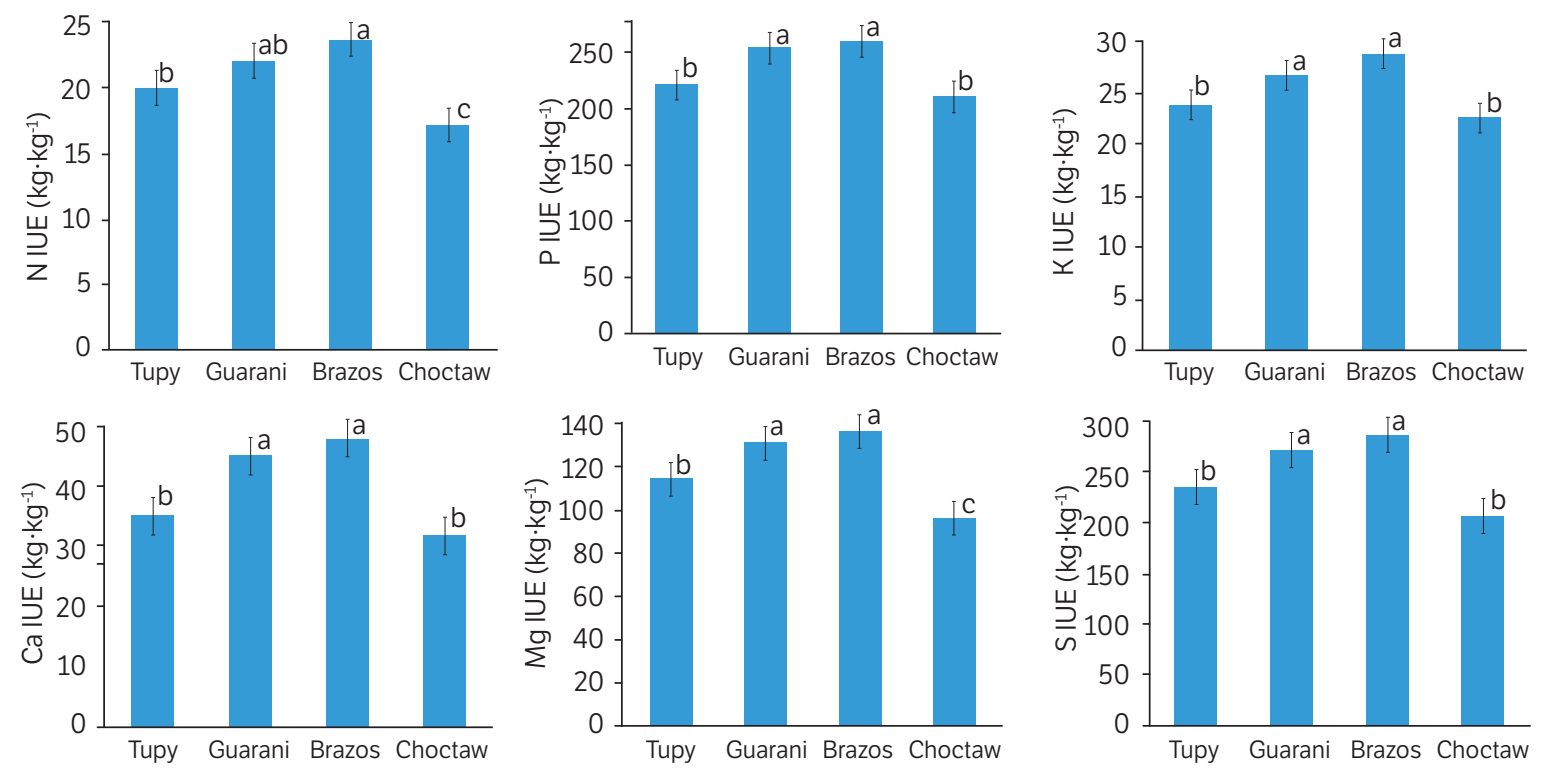

Figure 14. Internal utilization efficiency (IUE) of N, P, Ca, Mg and S of four blackberry cultivars (IUE = phytomass accumulated in fruits/total nutrient uptake).

Note. Bars headed by different letters indicate that the IUE values of nutrients differ among cultivars (Tukey's HSD test, $p<0.05$ ). Means of the values observed in two cultivation cycles. Whiskers represent the $95 \%$ confidence intervals of the means. 
Table 2 shows an estimate of costs and revenues resulting from the application of $\mathrm{N}$ and $\mathrm{K}$ in a blackberry orchard during two production cycles. Both $\mathrm{N}$ and $\mathrm{K}$ fertilization have the potential to increase revenue accumulated in two production cycles over US\$ 3,500 per ha. The economic return for each US\$ spent on N fertilization was approximately US\$ 15 . For K fertilization, the economic return was nearly US\$ 40. Strik (2017) highlights the importance of yield increases due to the application of fertilizers as they help in the return on investments in the orchard.

All things considered, orchard management for subtropical regions in which all phytomass (fruits + leaves + canes) and nutrients contained therein are removed from the area each year requires fertilizers that replace all nutrients exported with phytomass, in addition to replacing nutrient losses from the soil-plant system due to runoff, leaching and volatilization. Another important change in the nutritional dynamics compared to conventional pruning management is a result of the imposition on plants having to produce canes, flowers and fruit in less than a year. It is likely that this more intensive management of blackberry orchards proposed for subtropical regions implies greater blackberry nutritional requirements compared to conventional biennial fruit production in which plants have a longer period to accumulate reserves.

Table 2. Estimates of costs, increases in productivity and revenue due to nitrogen and potassium fertilization for blackberry in two production cycles.

\begin{tabular}{|c|c|c|c|c|c|c|}
\hline \multirow{3}{*}{ Fertilizer $^{1}$} & \multirow{3}{*}{$\begin{array}{c}\text { Cost }^{2} \\
\text { US\$ } \$ h^{-1}\end{array}$} & \multirow{2}{*}{ Yield $^{3}$} & \multirow{2}{*}{ Increase $^{4}$} & \multicolumn{3}{|c|}{ Income } \\
\hline & & & & Gross $^{5}$ & $\mathrm{Net}^{6}$ & Increase $^{7}$ \\
\hline & & \multicolumn{2}{|c|}{$\longrightarrow$ Mg $\cdot h a^{-1}$} & \multicolumn{3}{|c|}{ US\$ ha $^{-1}$} \\
\hline Control & 0 & 7.4 & 0 & 16,086 & 16,086 & 0 \\
\hline$+\mathrm{N}$ & 240 & 9.3 & $1.8(25 \%)$ & 20,038 & 19,798 & $3,712(23 \%)$ \\
\hline$+\mathrm{K}$ & 94 & 9.2 & $1.7(23 \%)$ & 19,816 & 19,722 & $3,636(23 \%)$ \\
\hline
\end{tabular}

Note. ${ }^{1}$ Control $=$ no N or K applied, $+\mathrm{N}=121 \mathrm{~kg} \cdot \mathrm{ha}^{-1} \cdot \mathrm{cycle}^{-1}$ of N and $+\mathrm{K}=67 \mathrm{~kg} \cdot \mathrm{ha}^{-1} \cdot \mathrm{cycle}^{-1}$ of $\mathrm{K}_{2} \mathrm{O} ;{ }^{2}$ cost of applied fertilizer during two crop cycles $(+\mathrm{N}$ : annual $\mathrm{N}$ dose $\times 2 \times$ US\$ $0.99 \cdot \mathrm{kg}^{-1} ;+\mathrm{K}$ : annual $\mathrm{K}_{2} \mathrm{O}$ dose $\times 2 \times \mathrm{US} \$ 0.70 \cdot \mathrm{kg}^{-1}$ of $\mathrm{K}_{2} \mathrm{O}$ ); ${ }^{3}$ cumulative yield of two crop cycles (mean of four cultivars); ${ }^{4}$ yield increase due to fertilization in relation to the control treatment; ${ }^{5}$ gross income $=$ yield $\times$ fruit FOB price $\left(\right.$ US $\left.\$ 2.16 \cdot \mathrm{kg}^{-1}\right) ;{ }^{6}$ net income $=$ gross income - fertilizer cost; ${ }^{7}$ income increase due to fertilization in relation to the control treatment. Values in brackets indicate the percentage of increase in relation to the control treatment. US Dollar to Brazil Real average exchange rate in 2016/2017: US\$1.00 = R\$ 3.34.

\section{CONCLUSION}

Considering fruit yield, accumulation of phytomass and mineral elements, as well as the NUE, the cultivars that showed greater adaptation to cultivation in a subtropical area under drastic summer pruning management are 'Brazos', 'Guarani', 'BRS Tupy' and 'Choctaw', in that order.

An annual application of 120 and $67 \mathrm{~kg} \cdot \mathrm{ha}^{-1}$ of $\mathrm{N}$ and $\mathrm{K}_{2} \mathrm{O}$, respectively, is expected to be sufficient to achieve maximum economic yield.

Nutritional status assessment of blackberries grown in subtropical regions and subjected to drastic summer pruning requires the establishment of new reference values for mineral-element leaf contents.

\section{AUTHORS' CONTRIBUTION}

Conceptualization: Teixeira, L. and Bettiol Neto, J. E.; Methodology: Teixeira, L. and Bettiol Neto, J. E.; Investigation: Teixeira, L., Bettiol Neto, J. E., Sanchez, J. and Pio, R.; Writing - Original Draft: Teixeira, L. and Bettiol Neto, J. E.; Writing - Review and Editing: Teixeira, L., Bettiol Neto, J. E., Sanchez, J. and Pio, R.; Resources: Teixeira, L., Bettiol Neto, J. E., Sanchez, J. and Pio, R.

\section{DATA AVAILABILITY STATEMENT}


The datasets generated during and/or analyzed during the current study are available from the corresponding author on reasonable request.

\section{FUNDING}

Conselho Nacional de Desenvolvimento Científico e Tecnológico

[https://doi.org/10.13039/501100003593]

Grant n 448846/2014-4

\section{ACKNOWLEDGMENTS}

Not applicable.

\section{REFERENCES}

Antunes, L. E. C. and Raseira, M. C. B. (2004). Aspectos técnicos da cultura da amora-preta [Documentos 122]. Pelotas: Embrapa Clima Temperado.

Antunes, L. E. C., Gonçalves, E. D. and Trevisan, R. (2010). Fenologia e produção de cultivares de amoreira-preta em sistema agroecológico. Ciência Rural, 40, 1929-1933. https://doi.org/10.1590/S0103-84782010000900012

Antunes, L. E. C., Pereira, I. S., Picolotto, L., Vignolo, G. K. and Gonçalves, M. A. (2014) Produção de amoreira-preta no Brasil. Revista Brasileira de Fruticultura, 36, 100-111. https://doi.org/10.1590/0100-2945-450/13

Baligar, V. C., Fageria, N. K. and He, Z. L. (2001). Nutrient use efficiency in plants. Communications in Soil Science and Plant Analysis, 32, 921-950. https://doi.org/10.1081/CSS-100104098

Campagnolo, M. A. and Pio, R. (2012). Poda drástica para a produção da amora preta em regiões subtropicais. Pesquisa Agropecuária Brasileira, 47, 934-938. https://doi.org/10.1590/S0100-204X2012000700009

Climate-Data.Org. (2019). Climate Jundiaí (Brazil). [Accessed Dec. 30, 2020]. Available at: https://en.climate-data.org/south-america/ brazil/sao-paulo/jundiai-749/

[CQFS] Comissão de Química e Fertilidade do Solo. (2016). Manual de adubação e calagem para os estados do Rio Grande do Sul e Santa Catarina. Porto Alegre: Sociedade Brasileira de Ciência do Solo.

Croge, C. P., Cuquel, F. L., Biasi, L. A. and Bona, C. M. (2016). Performance of blackberry cultivars in Cerro Azul - PR. Revista Brasileira de Fruticultura, 38, e-141. https://doi.org/10.1590/0100-29452016141

Curi, P. N., Pio, R., Moura, P. H. A., Tadeu, M. H., Nogueira, P. V. and Pasqual, M. (2015). Produção de amora-preta e amora-vermelha em Lavras - MG. Ciência Rural, 45, 1368-1374. https://doi.org/10.1590/0103-8478cr20131572

Fernandez-Salvador, J., Strik, B. C. and Bryla, D. R. (2015). Response of Blackberry Cultivars to Fertilizer Source during Establishment in an Organic Fresh Market Production System. HortTechnology, 25, 277-292. https://doi.org/10.21273/HORTTECH.25.3.277

Fixen, P., Brentrup, F., Bruulsema, T. W., Garcia, F., Norton, R. and Zingore, S. (2015). Nutrient/fertilizer use efficiency: measurement, current situation and trends. In: P. Drechsel, P. Heffer, H. Magen, R. Mikkelsen and D. Wichelns (Eds.), Managing Water and Fertilizer for Sustainable Agricultural Intensification (p. 8-38). Paris: IFA/IWMI/IPNI/IPI. 
Grandall, P. C. (1995). Bramble production: the management and marketing of raspberries and blackberries. Boca Raton: CRC Press. https://doi.org/10.1201/9780429259166

Hart, J., Strik, B. and Rempel, H. (2006). Caneberries [Nutrient Management Guide EM8903-E]. Corvallis: Oregon State University.

Hawkesford, M., Horst, W., Kichey, T., Lambers, H., Schjoerring, J., Møller, I. S. and White, P. (2012). Functions of Macronutrients. In P. Marschner (Ed.), Marschner's Mineral Nutrition of Higher Plants (p.135-189). London: Elsevier. https://doi.org/10.1016/B978-0-12-384905-2.00006-6

Hochmuth, G., Hanlon., E. and Overman, A. (2011) Fertilizer experimentation, data analyses, and interpretation for developing fertilization recommendations_examples with vegetable crop research. Department of Soil and Water Sciences, UF/IFAS Extension, SL345.

[IFA] International Fertilizer Association; [WFO] World Farmers' Organization; [GACSA] GACSA Facilitation Unit. (2016). Nutrient Management Handbook. [Accessed Nov. 23, 2020]. Available at: https://www.fertilizer.org/images/Library_Downloads/2016_Nutrient_ Management_Handbook.pdf

Jones Junior, J. B. and Case, V. W. (1990). Sampling, handling, and analyzing plant tissue samples. In R. L. Westerman (Ed.), Soil Testing and Plant Analysis (p. 389-427). Madison: Soil Science Society of America. https://doi.org/10.2136/sssabookser3.3ed.c15

Marini, R. P. (2003). Approaches to Analyzing Experiments with Factorial Arrangements of Treatments Plus Other Treatments. HortScience, 38, 117-120. https://doi.org/10.21273/HORTSCI.38.1.117

Martins, F. P. (1998). Amora-preta. In J. I. Fahl, M. B. P. Camargo, M. A. Pizzinato, J. A. Betti, A. M. T. Melo, I. C. DeMaria and A. M. C. Furlan (Eds.), Instruções agrícolas para as principais culturas econômicas. Campinas: IAC.

Moura, P. H. A., Campagnolo, M. A., Pio, R., Curi, P. N., Assis, C. N. and Silva, T. C. (2012). Fenologia e produção de cultivares de framboeseiras em regiões subtropicais no Brasil. Pesquisa Agropecuária Brasileira, 47,1714-1721. https://doi.org/10.1590/S0100-204X2012001200006

Natale, W., Rozane, D. E., Parent, S.-É and Parent, L. E. (2012). Soil Acidity and Liming in Tropical Fruit Orchards. In R. N. Issaka (Ed.), Soil Fertility (p. 173-192). London: IntechOpen. https://doi.org/10.5772/53345

Pedro Junior, M. J., Ortolani, A. A., Rigitano, O., Alfonsi, R. R., Pinto, H. S. and Brunini, O. (1979). Estimativa de horas de frio abaixo de 7 e de $13^{\circ} \mathrm{C}$ para regionalização da fruticultura de clima temperado no estado de São Paulo. Bragantia, 38, 123-130. https://doi.org/10.1590/ S0006-87051979000100013

Pereira, I. S., Picolotto, L., Gonçalves, M. A., Vignolo, G. K. and Antunes, L. E. C. (2015). Potassium fertilization affects floricane mineral nutrient content, growth, and yield of blackberry grown in Brazil. HortScience, 50, 1234-1240. https://doi.org/10.21273/HORTSCI.50.8.1234

Pereira, I. S., Bamberg, A. L., Silveira, C. A. P., Antunes, L. E. C. and Souza, R. O. (2020). Nitrogen Fertilization in Blackberry. In E. Rigobelo and A. Serra (Eds.), Nitrogen Fixation. Rijeka: IntechOpen. https://doi.org/10.5772/intechopen.82409

van Raij, B., Cantarella, H., Quaggio, J. A. and Furlani, A. M. C. (1997). Recomendações de adubação e calagem para o Estado de São Paulo. Campinas: IAC.

van Raij, B., Andrade, J. C., Cantarella, H. and Quaggio, J. A. (2001). Análise química para avaliação da fertilidade de solos tropicais. Campinas: IAC.

Riedell, W. E. (2010). Mineral-nutrient synergism and dilution responses to nitrogen fertilizer in field-grown maize. Journal of Plant Nutrition and Soil Science, 173, 869-874. https://doi.org/10.1002/jpln.200900218

SAS Institute (2004). SAS OnlineDoc ${ }^{\oplus}$ 9.1.3. Cary: SAS Institute Inc. [Accessed Nov. 23, 2020]. Available at: https://support.sas.com/ documentation/onlinedoc/91pdf/index_913.html

Singh, B. and Ryan, J. (2015). Managing fertilizers to enhance soil health. Paris: IFA.

Spiers, J. M. and Braswell, J. H. (2002). Influence of N, P, K, Ca, and Mg rates on leaf macronutrient concentration of 'Navaho' blackberry. Acta Horticulturae, 585, 659-663. https://doi.org/10.17660/ActaHortic.2002.585.109 
Strik, B. C. (2008). A review of nitrogen nutrition of Rubus. Acta Horticulturae, 777, 403-410. https://doi.org/10.17660/ActaHortic.2008.777.61

Strik, B. C. (2017). Plant Nutrient Management. In H. K. Hall and R. C. Funt (Eds.), Blackberries and their hybrids (p.146-168). Wallingford: CABI. https://doi.org/10.1079/9781780646688.0146

Strik, B. C. and Bryla, D. R. (2015). Uptake and partitioning of nutrients in blackberry and raspberry and evaluating plant nutrient status for accurate assessment of fertilizer requirements. HortTechnology, 25, 452-459. https://doi.org/10.21273/HORTTECH.25.4.452

Tadeu, M. H., Souza, F. B. M., Pio, R., Valle, M. H. R., Locatelli, G., Guimarães, G. F. and Silva, B. E. C. (2015). Poda drástica de verão e produção de cultivares de amoreira preta em região subtropical. Pesquisa Agropecuária Brasileira, 50, 132-140. https://doi.org/10.1590/ S0100-204X2015000200005

Tian, D. and Niu, S. (2015). A global analysis of soil acidification caused by nitrogen addition. Environmental Research Letters, 10, 024019. https://doi.org/10.1088/1748-9326/10/2/024019

Willcutts, J. F., Overman, A. R., Hochmuth, G. J., Cantliffe, D. J. and Soundy, P. (1998). A Comparison of Three Mathematical Models of Response to Applied Nitrogen: A Case Study Using Lettuce. HortScience, 33, 833-836. https://doi.org/10.21273/HORTSCI.33.5.833 